\title{
Phase composition and magnetic properties of $\mathrm{Ni}_{1-x} \mathrm{Co}_{x} \mathrm{Fe}_{2} \mathrm{O}_{4}$ nanocrystals with spinel structure, synthesized by Co-precipiation
}

\author{
Anh Tien Nguyen ${ }^{1}$, Tien Dat Nguyen ${ }^{1}$, V. O. Mittova $^{2}$, M. V. Berezhnaya ${ }^{3}$, I. Ya. Mittova ${ }^{3}$ \\ ${ }^{1}$ Ho Chi Minh City Pedagogical University, Ho Chi Minh City, Vietnam \\ ${ }^{2}$ Burdenko Voronezh State Medical University, Voronezh 394036, Russia \\ ${ }^{3}$ Voronezh State University, Voronezh 394018, Russia \\ anhtienhcmup@gmail.com, tiendatpn@gmail.com,vmittova@mail.ru, \\ cnurova2010@yandex.ru, imittova@mail.ru
}

PACS 75.50.Cc, 81.07.Wx

DOI 10.17586/2220-8054-2017-8-3-371-377

\begin{abstract}
Nanopowders of nickel ferrite doped with cobalt were synthesized by co-precipitation using a $3 \% \mathrm{KOH}$ solution as a precipitant. The effects of different annealing regimes on the composition and particle size of $\mathrm{Ni}_{1}{ }_{x} \mathrm{Co}_{x} \mathrm{Fe}_{2} \mathrm{O}_{4}$ were studied. It was established that with annealing at $t=1000{ }^{\circ} \mathrm{C}$ for $2 \mathrm{~h}$ single-phase products were formed with a crystallite size of $30-50 \mathrm{~nm}$. The saturation magnetization and the coercive force increased as the content of the dopant increased from $50.3 \mathrm{emu} / \mathrm{g}$ and $51.94 \mathrm{Oe}$ for $\mathrm{NiFe}_{2} \mathrm{O}_{4}$ to $80.45 \mathrm{emu} / \mathrm{g}$ and $848.32 \mathrm{Oe}$ for $\mathrm{CoFe} \mathrm{O}_{4}$.
\end{abstract}

Keywords: ferrites, spinel, nanocrystals, co-precipitation, magnetic properties.

Received: 7 April 2017

Revised: 12 May 2017

\section{Introduction}

Among magnetic materials, nanocrystalline ferrites with a spinel structure of type $\mathrm{MFe}_{2} \mathrm{O}_{4}(\mathrm{M}=\mathrm{Co}, \mathrm{Ni}, \mathrm{Zn}$, $\mathrm{Mn}$ ) are distinguished by high permeability, saturation magnetization and are used to produce new multifunctional materials, such as high-frequency devices, due to the decreased Foucault currents and increased duration of their functioning [1-5]. In addition, ferrites with a spinel structure are cheaper and more stable (in terms of time and temperature) compared to metals and alloys.

The magnetic and electrical characteristics of these ferrites depend on their chemical composition, cation location, particle size, dopant content and the synthesis method [1-9]. $\mathrm{CoFe}_{2} \mathrm{O}_{4}$ is hard magnetic ferrite with a high coercive force $\mathrm{H}_{c}>1500 \mathrm{Oe}$, with an average saturation magnetization of $\mathrm{M}_{s} \sim 40 \mathrm{emu} / \mathrm{g}[10]$. $\mathrm{NiFe}_{2} \mathrm{O}_{4}$ is a soft magnetic material characterized by small values of coercive force, saturation magnetization and excessive magnetization $\left(\mathrm{H}_{c}=46.46 \mathrm{Oe}, \mathrm{M}_{s}=8.8 \mathrm{emu} / \mathrm{g}, \mathrm{M}_{r}=0.2 \mathrm{emu} / \mathrm{g}\right)$ [1-3]. Different magnetic properties of ferrites are required for different applications and can be achieved in several ways: either by controlling the particle size, or by changing the concentrations of hard and soft magnetic phases in the material by introduction of another element (dopant) or by the formation of coatings on $\mathrm{SiO}_{2}$ [11-14].

Sol-gel processes, including the formation of complexes with the addition of surfactants are promising for the synthesis of ferromagnetic oxide nanomaterials $\mathrm{MFe}_{2} \mathrm{O}_{4}(\mathrm{M}=\mathrm{Co}$, Ni). An important advantage of such complexes is the lower annealing temperature in comparison to solid-phase synthesis, leading to decreased size of the obtained particles $[2-5,10,11]$. However, the formation of a single-phase product synthesized by the sol-gel method is affected by many factors, such as the annealing temperature and time, the gel formation temperature, the stoichiometry of the surfactant/metal ions, $\mathrm{pH}$ value, and others.

In previous studies $[1,12], \mathrm{MFe}_{2} \mathrm{O}_{4}$ nanocrystals $(\mathrm{M}=\mathrm{Co}, \mathrm{Ni})$ were obtained by co-precipitation of $\mathrm{M}^{2+}$ and $\mathrm{Fe}^{3+}$ cations at room temperature with the addition of an aqueous ammonia at $\mathrm{pH}=11$. However, at $\mathrm{pH}=11$, $\mathrm{Co}(\mathrm{OH})_{2}$ and $\mathrm{Ni}(\mathrm{OH})_{2}$ are dissolved with the formation of complexes with ammonia in accordance with the following equation:

$$
\mathrm{M}(\mathrm{OH})_{2} \downarrow+6 \mathrm{NH}_{3} \rightarrow\left[\mathrm{M}\left(\mathrm{NH}_{3}\right)_{6}\right](\mathrm{OH})_{2},
$$

therefore, it is impossible to completely precipitate cobalt and nickel hydroxides with an aqueous solution of ammonia, which makes the achievement of the molar ratio $\mathrm{M}^{2+}: \mathrm{Fe}^{3+}=1: 2$ in the composition of precipitation complicated.

In this study, we investigated conditions for the formation of nanocrystals with the spinel structure $\mathrm{Ni}_{1-x} \mathrm{Co}_{x} \mathrm{Fe}_{2} \mathrm{O}_{4}(x=0 ; 0.2 ; 0.4 ; 0.6 ; 0.8 ; 1)$ by co-precipitation during the hydrolysis of $\mathrm{M}(\mathrm{II})$ and $\mathrm{Fe}(\mathrm{III})$ cations in boiling water, followed by cooling and addition of $3 \%$ aqueous $\mathrm{KOH}$ as a precipitant, as well as the phase composition and magnetic properties of the formed compounds. Hydrolysis of $\mathrm{M}$ (II) and Fe(III) cations in 
boiling water leads to the formation of a stable precipitate and decreased particle size compared to co-precipitation of the hydroxide ions at room temperature. Some nanosystems of $\mathrm{LnFeO}_{3}(\mathrm{Ln}=\mathrm{La}, \mathrm{Y})$ type were obtained by this co-precipitation method $[15,16]$.

\section{Materials and methods}

\subsection{Initial substances}

The precursors for these syntheses were aqueous solutions of nickel (II), cobalt (II) and iron (III) nitrates (all chemically pure) with a molar ratio of $\mathrm{Ni}^{2+}: \mathrm{Co}^{2+}: \mathrm{Fe}^{3+}=(1-x): x: 2$. The precipitant was an aqueous solution of potassium hydroxide ( $3 \%$ ).

\subsection{The synthesis of $\mathrm{Ni}_{1-x} \mathrm{Co}_{x} \mathrm{Fe}_{2} \mathrm{O}_{4}$ nanoparticles}

$\mathrm{Ni}_{1-x} \mathrm{Co}_{x} \mathrm{Fe}_{2} \mathrm{O}_{4}$ nanoparticles were synthesized by adding $50 \mathrm{~mL}$ of a mixture containing $\mathrm{Ni}\left(\mathrm{NO}_{3}\right)_{2} 0.1 \mathrm{M}$, $\mathrm{Co}\left(\mathrm{NO}_{3}\right)_{2} 0.1 \mathrm{M}$ and $\mathrm{Fe}\left(\mathrm{NO}_{3}\right)_{3} 0.2 \mathrm{M}$ into $500 \mathrm{~mL}$ of boiling water with magnetic stirring. The obtained colloidal system was cooled to room temperature. The system acquired a reddish-brown color which it retained upon cooling. Then, $3 \%$ aqueous solution of potassium hydroxide in the amount required for complete precipitation of the cations (until the disappearance of the phenolphthalein color) was added with magnetic stirring.

The precipitated hydroxides were stirred for 30-40 min with magnetic stirring. The obtained precipitate was separated using a vacuum filter, washed several times with distilled water and dried at room temperature to a constant weight.

\subsection{Methods of investigation}

The obtained samples were finely ground into a powder and subjected to complex thermal analysis using thermal analyzer Labsys Evo (TG-DSC $1600{ }^{\circ} \mathrm{C}$, France), including thermogravimetric analysis (TGA) and differential-scanning calorimetry (DSC). The thermal analysis was carried out in the dry air. The heating rate was $10 \%$ min; the maximum heating temperature was $1100^{\circ} \mathrm{C}$.

The phase compositions of the samples were determined by X-ray phase analysis (XPA, diffractometer SIEMEN D - 5000 Brucker, Germany), $\mathrm{CuK}_{\alpha}$-radiation, $\lambda=0.15406 \mathrm{~nm}, 2 \theta=10-80^{\circ}$, measurement interval $0.02 \%$ sec. The obtained diffractograms were analyzed using the JCPDS database.

The average crystal size according to XPA data and the constant parameter of the spinel cubic lattice $\mathrm{Ni}_{1-x} \mathrm{Co}_{x} \mathrm{Fe}_{2} \mathrm{O}_{4}$ were calculated by following equations:

$$
\begin{gathered}
d=\frac{0.89 \cdot \lambda}{\beta \cos \theta}, \\
a=\frac{\lambda}{2 \sin \theta} \sqrt{h^{2}+k^{2}+l^{2}},
\end{gathered}
$$

where $d$ - average crystal size, $\AA ; \lambda$ - X-ray tube wavelength (for the copper tube used in this recording, $\lambda=0.15406 \mathrm{~nm}$ ); $2 \theta-$ is the position of the maximum of the peak, deg; $\beta$ - is the true physical broadening of the diffraction maximum, rad.; $h, k, l$ - Miller indices, correspond to the peaks with the highest intensity.

The sizes and morphologies of the nanoparticles were determined by transmission electron microscopy (TEMJEOL 1400, Japan).

Magnetic characteristics of $\mathrm{Ni}_{1-x} \mathrm{Co}_{x} \mathrm{Fe}_{2} \mathrm{O}_{4}$ nanopowders were studied using a Microsene EV11 (Japan) vibration magnetometer at room temperature.

\subsection{Results and discussion}

The results of complex thermal analysis of the obtained precipitate for $\mathrm{Ni}_{0.6} \mathrm{Co}_{0.4} \mathrm{Fe}_{2} \mathrm{O}_{4}$ nanopowder before annealing, shown in Fig. 1, demonstrated that mass loss of the sample during all heat treatment processes from room temperature to $1100{ }^{\circ} \mathrm{C}$ was $16.61 \%$ (TGA curve). The mass loss of the sample heated from $65^{\circ} \mathrm{C}$ to $320^{\circ} \mathrm{C}$ occurs rapidly, as indicated by the slope of TGA curve. Two peaks of endothelial effects at $200{ }^{\circ} \mathrm{C}$ and $27^{\circ} \mathrm{C}$, characteristic for desorption, evaporation and decomposition of nickel (II), cobalt (II) and iron (III) hydroxides were detected on DSC curve.

After that, the mass loss of the sample is slower, terminating at $\sim 650{ }^{\circ} \mathrm{C}$ due to the continuation of decomposition of hydroxides with formation of $\mathrm{NiO}, \mathrm{CoO}$ and $\mathrm{Fe}_{2} \mathrm{O}_{3}$. At this point, a large peak corresponding to heat release at $500-650{ }^{\circ} \mathrm{C}$ appeared.

Subsequently, in accordance with the thermal analysis data of $\mathrm{Ni}_{0.6} \mathrm{Co}_{0.4} \mathrm{Fe}_{2} \mathrm{O}_{4}$, thermal treatment was carried out at 700,800 and $1000^{\circ} \mathrm{C}$ for $2 \mathrm{~h}$ in order to establish the conditions for the formation of single-phase $\mathrm{Ni}_{1-x} \mathrm{Co}_{x} \mathrm{Fe}_{2} \mathrm{O}_{4}$ products. 


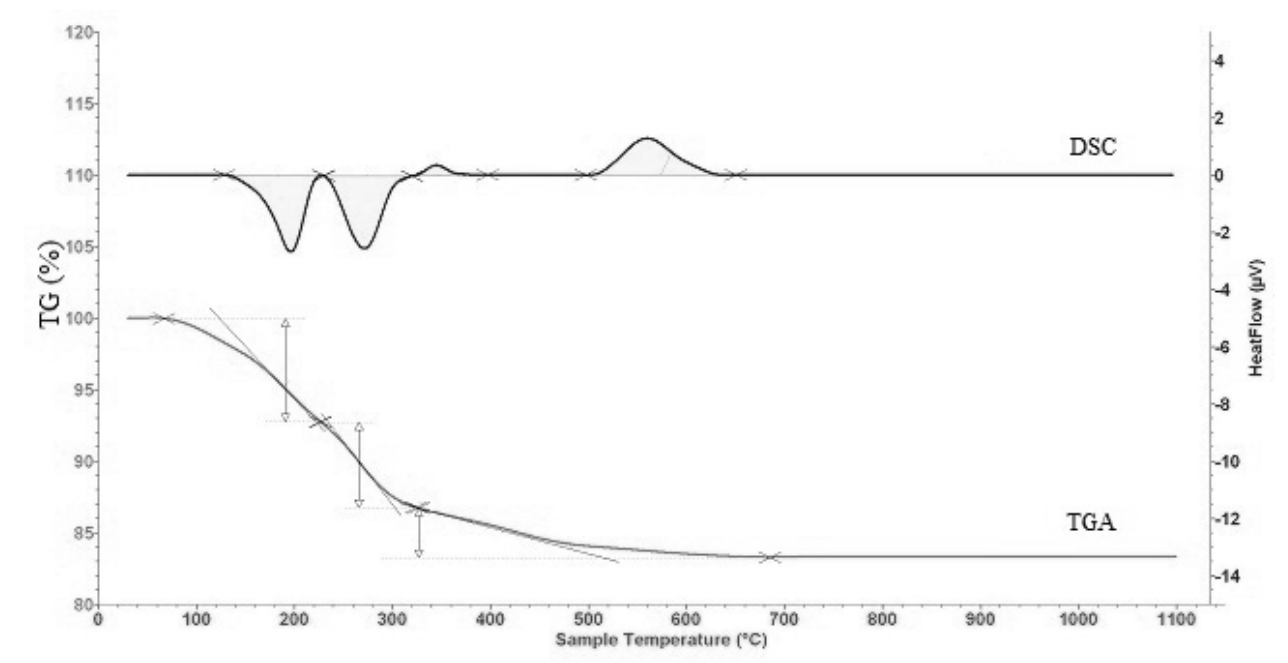

FIG. 1. DSC and TGA curves of precipitate sample for production of $\mathrm{Ni}_{0.6} \mathrm{Co}_{0.4} \mathrm{Fe}_{2} \mathrm{O}_{4}$ before annealing

The diffractograms of undoped $\mathrm{NiFe}_{2} \mathrm{O}_{4}$ (Fig. 2) after annealing at 700, 800 and $1000{ }^{\circ} \mathrm{C}$ showed that the background of lines of diffractograms are stable, the intensities of the peaks increase and their widths decrease at higher temperatures. Consequently, when the annealing temperature increased from $700{ }^{\circ} \mathrm{C}$ to $1000{ }^{\circ} \mathrm{C}$, the degree of crystallization of the samples increased with decreasing average crystal size. The presence of only one phase of $\mathrm{NiFe}_{2} \mathrm{O}_{4}$ spinel with a cubic structure belonging to Fd3m spatial group (JCPDS 00-010-0325) was detected in the diffractograms of all samples.

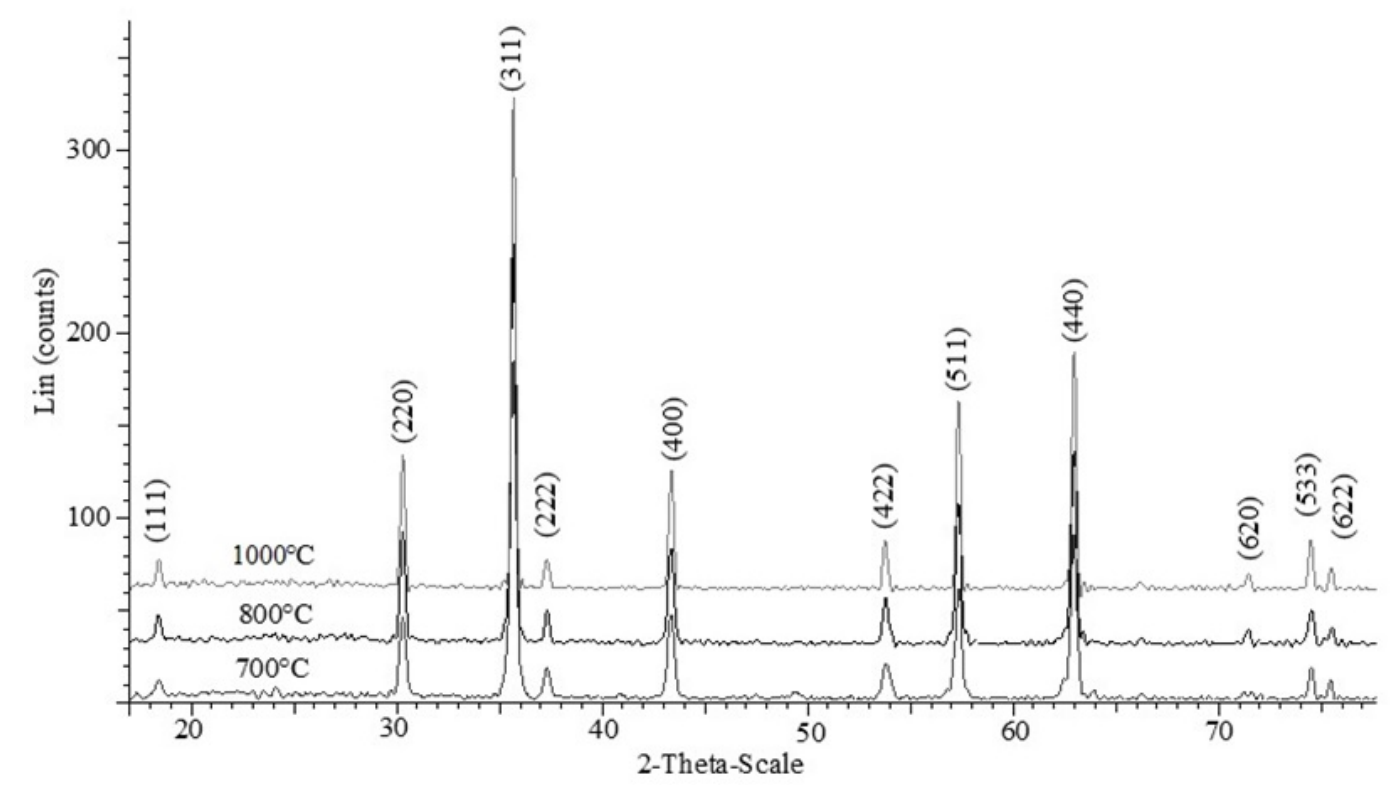

FIG. 2. Diffractograms of $\mathrm{NiFe}_{2} \mathrm{O}_{4}$ samples, obtained by the co-precipitation method after annealing at 700,800 and $1000{ }^{\circ} \mathrm{C}$ for $2 \mathrm{~h}$

In diffractograms of $\mathrm{CoFe}_{2} \mathrm{O}_{4}$ samples after annealing at 700,800 and $1000{ }^{\circ} \mathrm{C}$ (Fig. 3), peaks corresponding to only one phase $-\mathrm{CoFe}_{2} \mathrm{O}_{4}$ with a cubic structure belonging to the spatial Fd3m group (JCPDS 00-022-1086) were also present.

Later, in accordance with the XPA data of $\mathrm{MFe}_{2} \mathrm{O}_{4}$ samples $(\mathrm{M}=\mathrm{Ni}, \mathrm{Co})$, the following annealing modes were selected for the formation of $\mathrm{Ni}_{1-x} \mathrm{Co}_{x} \mathrm{Fe}_{2} \mathrm{O}_{4}(x=0.2,0.4,0.6$ and 0.8$)$ : temperature 800 and $1000{ }^{\circ} \mathrm{C}$, time $-2 \mathrm{~h}$.

$\mathrm{X}$-ray phase analysis (Figs. 4, 5) of the synthesized nanopowders demonstrated the formation of solid solutions between $\mathrm{NiFe}_{2} \mathrm{O}_{4}$ and $\mathrm{CoFe}_{2} \mathrm{O}_{4}[12,13]$, peaks with different $x$ values coincided with each other and with standard 


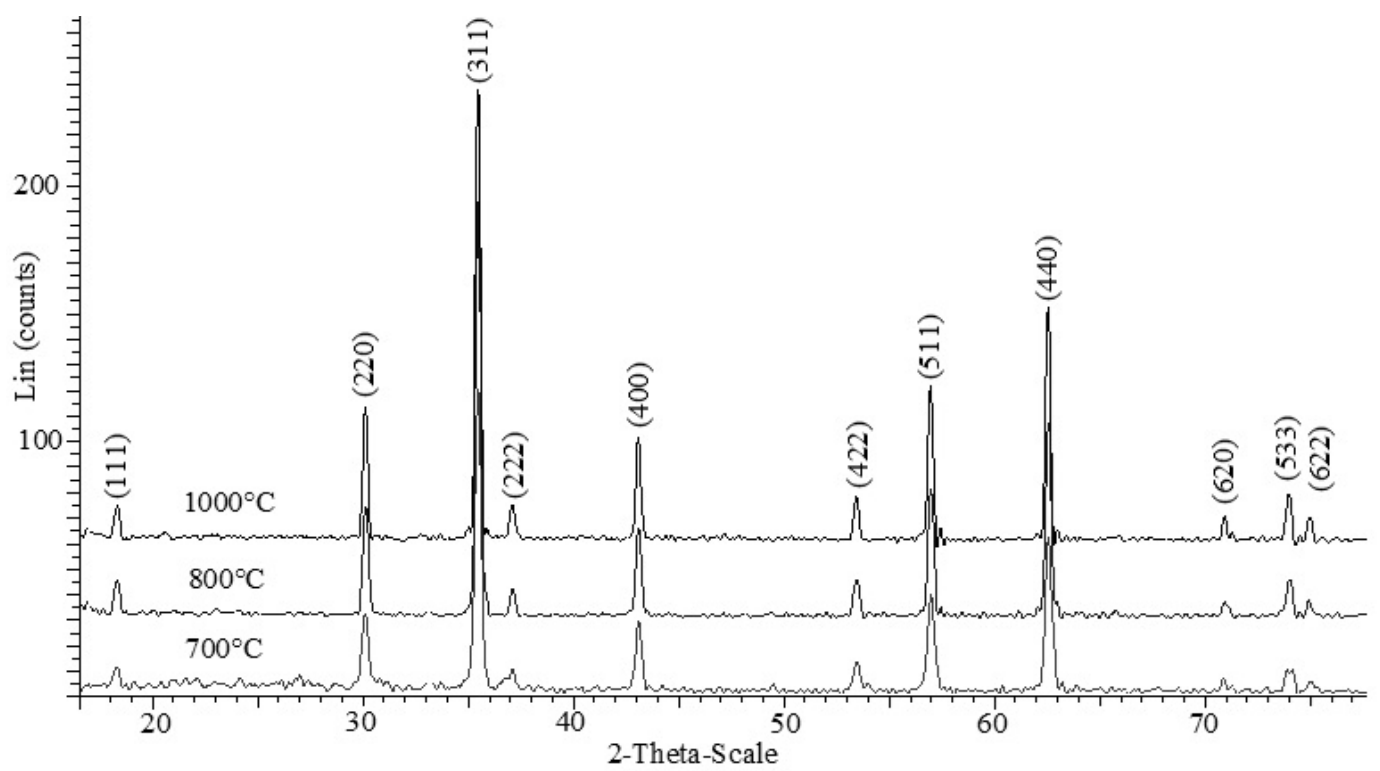

FIG. 3. Diffractograms of $\mathrm{CoFe}_{2} \mathrm{O}_{4}$ samples, obtained by the co-precipitation method after annealing at 700,800 and $1000{ }^{\circ} \mathrm{C}$ for $2 \mathrm{~h}$

diffractograms of JCPDS base. However, the slow scanning of the peak angles with the highest intensity (2 $\theta$ was from 34.5 to 35.5 deg., Miller's indices (311)) (Fig. 4) showed the shift of X-ray diffraction lines to the left (decrease of 2 $\theta$ ) as $x$ values increased (Fig. 5). This fact proves the substitution of nickel by cobalt in $\mathrm{Ni}_{1-x} \mathrm{Co}_{x} \mathrm{Fe}_{2} \mathrm{O}_{4}$ spinel [14]. The average size of crystals of $\mathrm{Ni}_{1-x} \mathrm{Co}_{x} \mathrm{Fe}_{2} \mathrm{O}_{4}$ spinel after annealing at 800 and $1000{ }^{\circ} \mathrm{C}$ for $2 \mathrm{~h}$, calculated by formula (1), was from 19 to $50 \mathrm{~nm}$ and it gradually increased with an increase in the degree of doping from $x=0$ to $x=0.6$, and then decreased. The parameter of the crystalline cubic lattice (a) of $\mathrm{Ni}_{1-x} \mathrm{Co}_{x} \mathrm{Fe}_{2} \mathrm{O}_{4}$ nanocrystals, calculated from formula (2), increased with increased annealing temperatures and cobalt content in the samples (Tables 1 and 2). The last trend can be explained by the fact that the ionic radius of $\mathrm{Ni}^{2+}(0.72 \AA)$ is lower than that of $\mathrm{Co}^{2+}(0.74 \AA)$ [11]. Similar results were obtained in studies [11,12, 14].

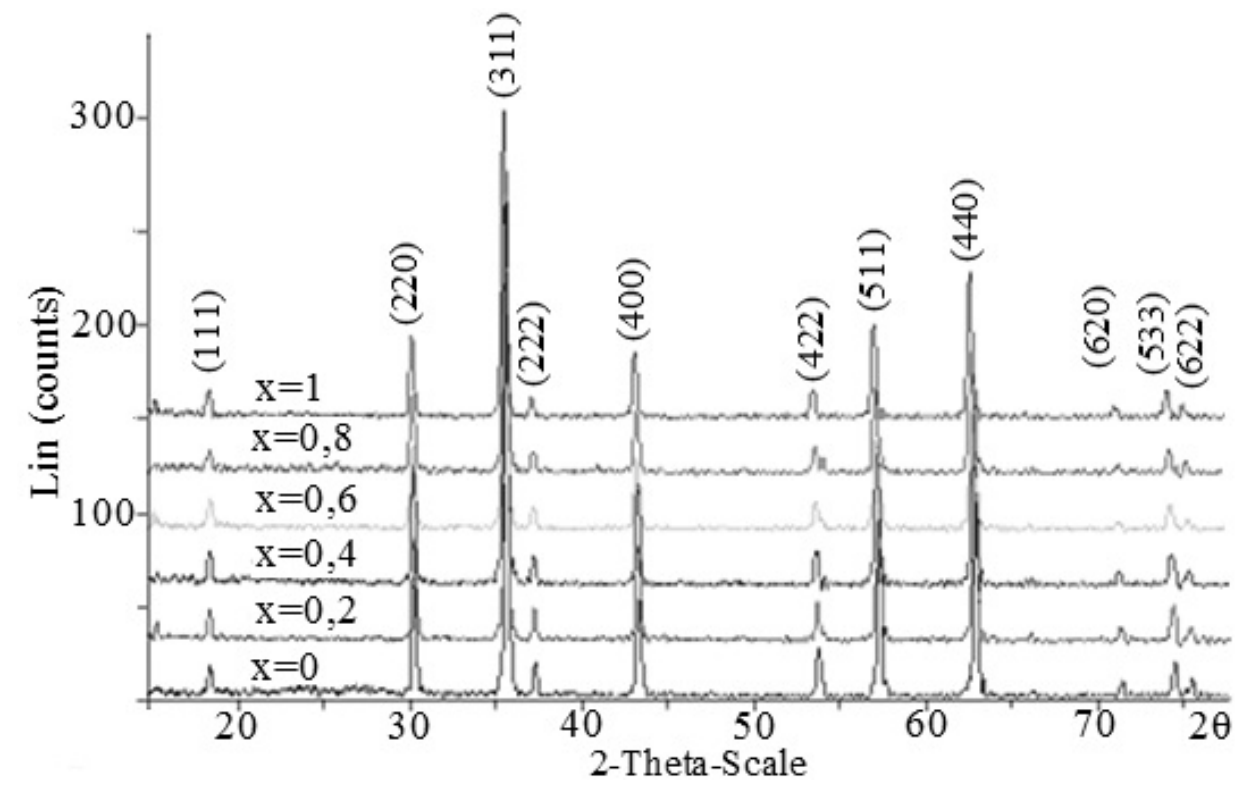

FIG. 4. Diffractograms of $\mathrm{Ni}_{1-x} \mathrm{Co}_{x} \mathrm{Fe}_{2} \mathrm{O}_{4}$ samples obtained by the co-precipitation method after annealing at $1000^{\circ} \mathrm{C}$ for $2 \mathrm{~h}$ 


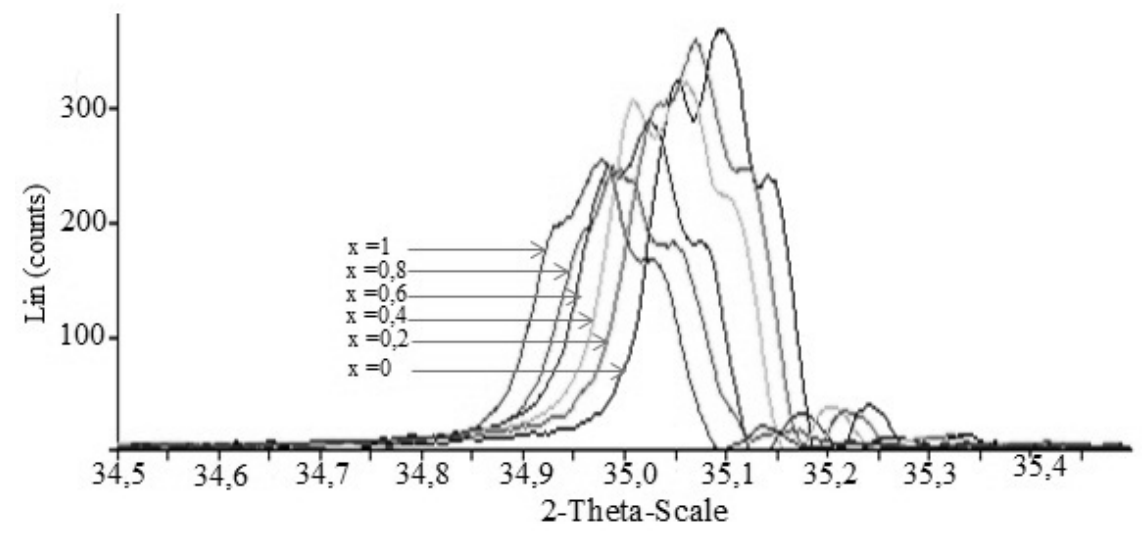

FIG. 5. Displacement of X-ray diffraction lines of $\mathrm{Ni}_{1-x} \mathrm{Co}_{x} \mathrm{Fe}_{2} \mathrm{O}_{4}$ samples after annealing at $1000{ }^{\circ} \mathrm{C}$ for $2 \mathrm{~h}$

TABLE 1. Parameters of crystalline structure of $\mathrm{Ni}_{1-x} \mathrm{Co}_{x} \mathrm{Fe}_{2} \mathrm{O}_{4}$ samples, synthesized by the co-precipitation method after annealing at $800{ }^{\circ} \mathrm{C}$ for $2 \mathrm{~h}$

\begin{tabular}{|c|c|c|c|c|c|c|}
\hline $\boldsymbol{x}$ & $\mathbf{0}$ & $\mathbf{0 . 2}$ & $\mathbf{0 . 4}$ & $\mathbf{0 . 6}$ & $\mathbf{0 . 8}$ & $\mathbf{1}$ \\
\hline $2 \theta_{\max }, \mathrm{deg}$ & 35.6714 & 35.6293 & 35.5707 & 35.5636 & 35.5244 & 35.4663 \\
\hline FWHM, rad. & 0.311 & 0.276 & 0.223 & 0.192 & 0.378 & 0.432 \\
\hline$D, \mathrm{~nm}$ & 26.540 & 33.202 & 38.195 & 42.969 & 22.187 & 19.092 \\
\hline$a, \AA$ & 8.311 & 8.351 & 8.364 & 8.366 & 8.375 & 8.387 \\
\hline
\end{tabular}

TABLE 2. Parameters of crystalline structure of $\mathrm{Ni}_{1-x} \mathrm{Co}_{x} \mathrm{Fe}_{2} \mathrm{O}_{4}$ samples synthesized by the co-precipitation method after annealing at $1000{ }^{\circ} \mathrm{C}$ for $2 \mathrm{~h}$

\begin{tabular}{|c|c|c|c|c|c|c|}
\hline $\boldsymbol{x}$ & $\mathbf{0}$ & $\mathbf{0 . 2}$ & $\mathbf{0 . 4}$ & $\mathbf{0 . 6}$ & $\mathbf{0 . 8}$ & $\mathbf{1}$ \\
\hline $2 \theta_{\text {max }}$, deg & 35.6756 & 35.6058 & 35.5881 & 35.5292 & 35.4835 & 35.4499 \\
\hline FWHM, rad. & 0.251 & 0.221 & 0.195 & 0.168 & 0.314 & 0.382 \\
\hline$D, \mathrm{~nm}$ & 32.880 & 39.139 & 42.311 & 49.113 & 26.204 & 21.590 \\
\hline$a, \AA$ & 8.340 & 8.356 & 8.366 & 8.373 & 8.384 & 8.392 \\
\hline
\end{tabular}

TEM images of $\mathrm{NiFe}_{2} \mathrm{O}_{4}, \mathrm{Ni}_{0.6} \mathrm{Co}_{0.4} \mathrm{Fe}_{2} \mathrm{O}_{4}$ and $\mathrm{CoFe}_{2} \mathrm{O}_{4}$ samples after annealing at $800{ }^{\circ} \mathrm{C}$ for $2 \mathrm{~h}$ (Fig. 6) showed that the size of the synthesized particles was $30-50 \mathrm{~nm}$.

The magnetization curves of $\mathrm{Ni}_{1-x} \mathrm{Co}_{x} \mathrm{Fe}_{2} \mathrm{O}_{4}$ samples, measured at room temperature are shown in Fig. 7, while their magnetic characteristics are shown in Table 3. Analysis of the obtained results shows that saturation magnetization $\left(M_{s}\right)$, excess magnetization $\left(M_{r}\right)$, and coercive force $\left(H_{c}\right)$ of $\mathrm{Ni}_{1-x} \mathrm{Co}_{x} \mathrm{Fe}_{2} \mathrm{O}_{4}$ samples increase with increased cobalt content in $\mathrm{NiFe}_{2} \mathrm{O}_{4}$ lattice. The increase in $M_{r}$ and $H_{c}$ values was due to an increase in the size of $\mathrm{Ni}_{1-x} \mathrm{Co}_{x} \mathrm{Fe}_{2} \mathrm{O}_{4}$ crystals as the cobalt content increased (see Table 2). The increase in saturation magnetization $\left(M_{s}\right)$ is explained by the fact that the magnetic moment of $\mathrm{Co}^{2+}$ cation $\left(\mu=3 \mu_{B}\right)$ is higher than the magnetic moment of $\mathrm{Ni}^{2+}$ ion $\left(\mu=2 \mu_{B}\right)$ [17].

Excess magnetization values of the samples $\left(M_{r}=7.58-38.45 \mathrm{emu} / \mathrm{g}\right)$ obtained in this study were not different from data published earlier [10-12], but coercive force value $\left(H_{c}=51.94-838.42 \mathrm{Oe}\right)$ decreased 2-3-fold depending on the value of $x$. The saturation magnetization $\left(M_{s}=50.3-80.45 \mathrm{emu} / \mathrm{g}\right)$ was not only higher than the saturation magnetization of $\mathrm{CoFe}_{2} \mathrm{O}_{4}$ spinel, but also much higher than the saturation magnetization of $\mathrm{NiFe}_{2} \mathrm{O}_{4}$ spinel [3, $4,10,17]$. In addition, the saturation magnetization value of $\mathrm{CoFe}_{2} \mathrm{O}_{4}$ nanocrystals synthesized in this study, after annealing at $1000{ }^{\circ} \mathrm{C}$ for $2 \mathrm{~h}\left(M_{s}=80.45 \mathrm{emu} / \mathrm{g}\right)$ was higher than the standard saturation magnetization value of $\mathrm{CoFe}_{2} \mathrm{O}_{4}$ multidimensional materials $\left(M_{s}=80 \mathrm{emu} / \mathrm{g}\right)$ [18].

Thus, $\mathrm{Ni}_{1-x} \mathrm{Co}_{x} \mathrm{Fe}_{2} \mathrm{O}_{4}$ nanocrystals, synthesized by simple co-precipitation method, take precedence over $\mathrm{CoFe}_{2} \mathrm{O}_{4}$ nanocrystals by $H_{c}$ value and over $\mathrm{NiFe}_{2} \mathrm{O}_{4}$ - by the value of $M_{s}$. 

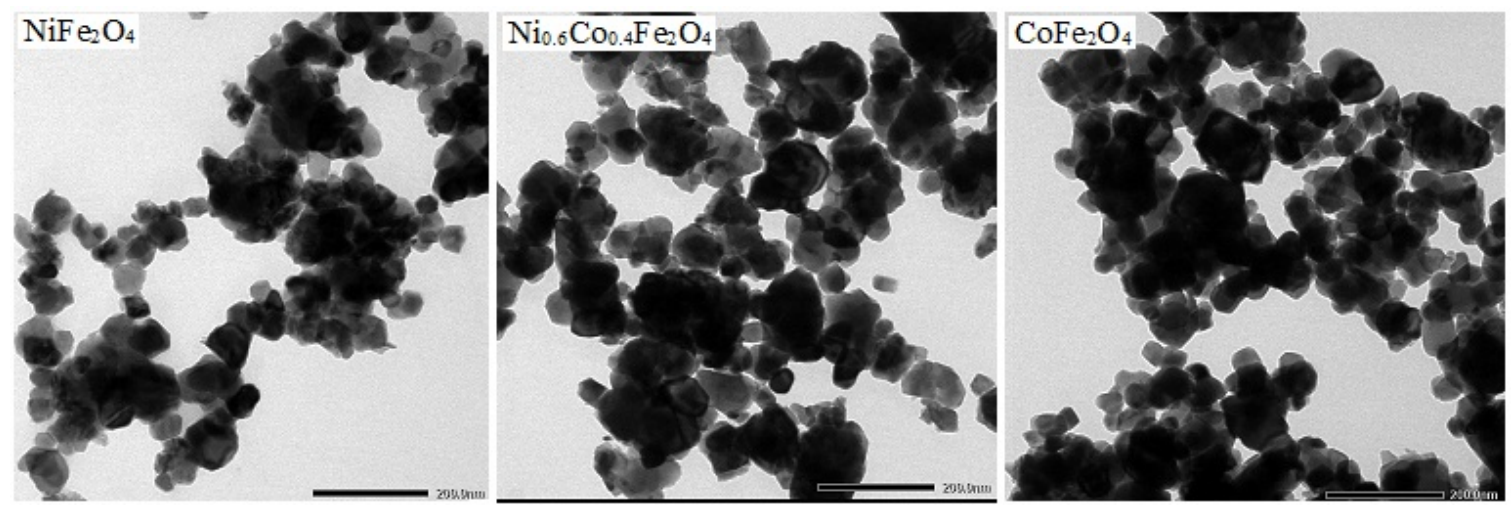

FIG. 6. TEM-images of $\mathrm{Ni}_{1-x} \mathrm{Co}_{x} \mathrm{Fe}_{2} \mathrm{O}_{4}$ powders after annealing at $800{ }^{\circ} \mathrm{C}$ during $2 \mathrm{~h}$
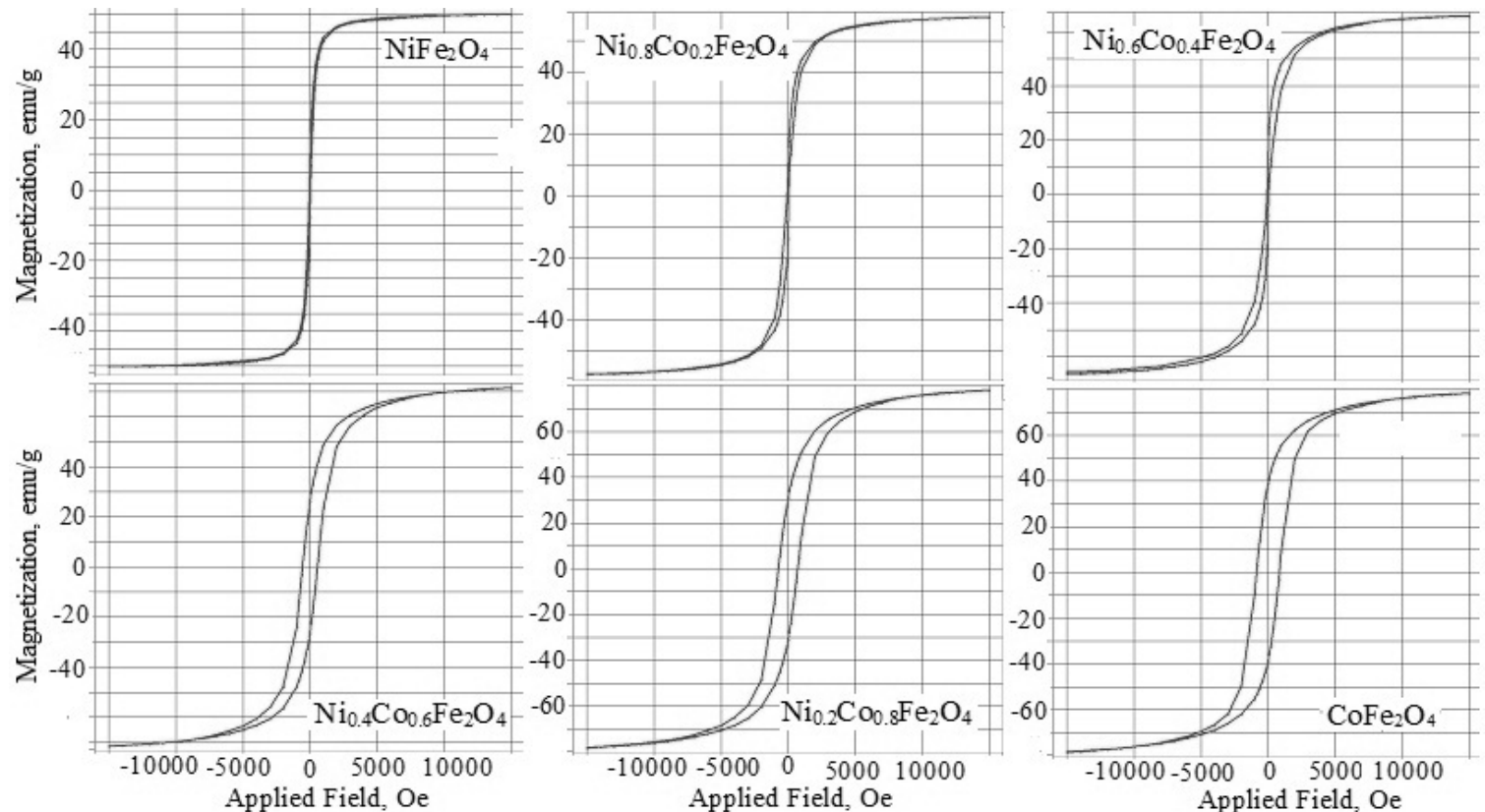

FIG. 7. Field dependence of magnetization of $\mathrm{Ni}_{1-x} \mathrm{Co}_{x} \mathrm{Fe}_{2} \mathrm{O}_{4}$, nanocrystals synthesized by the co-precipitation method after annealing at $1000{ }^{\circ} \mathrm{C}$ for $2 \mathrm{~h}$

TABLE 3. Magnetic characteristics of $\mathrm{Ni}_{1-x} \mathrm{Co}_{x} \mathrm{Fe}_{2} \mathrm{O}_{4}$ nanocrystals synthesized by the coprecipitation method after annealing at $1000{ }^{\circ} \mathrm{C}$ for $2 \mathrm{~h}$

\begin{tabular}{|c|c|c|c|}
\hline $\mathrm{Ni}_{1-x} \mathrm{Co}_{x} \mathrm{Fe}_{2} \mathrm{O}_{4}$ & $\mathrm{M}_{s}, \mathrm{emu} / \mathrm{g}$ & $\mathrm{M}_{r}, \mathrm{emu} / \mathrm{g}$ & $\mathrm{H}_{c}, \mathrm{Oe}$ \\
\hline$x=0$ & 50.3 & 7.58 & 51.94 \\
\hline$x=0.2$ & 57.57 & 9.93 & 70.49 \\
\hline$x=0.4$ & 66.07 & 10.26 & 73.41 \\
\hline$x=0.6$ & 71.44 & 26.41 & 547.89 \\
\hline$x=0.8$ & 78.16 & 30.96 & 706.26 \\
\hline$x=1$ & 80.45 & 38.45 & 848.32 \\
\hline
\end{tabular}




\section{Conclusions}

$\mathrm{Ni}_{1-x} \mathrm{Co}_{x} \mathrm{Fe}_{2} \mathrm{O}_{4}$ nanopowders $(x=0 ; 0.2 ; 0.4 ; 0.6 ; 0.8 ; 1)$ with a spinel structure were synthesized by a simple co-precipitation method using a $3 \%$ aqueous solution of $\mathrm{KOH}$ as a precipitant. Single-phase samples were formed by annealing the precipitates at 700,800 and $1000{ }^{\circ} \mathrm{C}$ for $2 \mathrm{~h}$. The obtained $\mathrm{Ni}_{1-x} \mathrm{Co}_{x} \mathrm{Fe}_{2} \mathrm{O}_{4}$ nanocrystals had a particle size of about $30-50 \mathrm{~nm}$. The size of their crystals, the cubic lattice, and the magnetic characteristics $\left(H_{c}, M_{r}\right.$ and $\left.M_{s}\right)$ increased with the increase of cobalt content in $\mathrm{NiFe}_{2} \mathrm{O}_{4}$ spinel.

\section{References}

[1] Ashiq M.N., Saleem S., Malana M.A., Anis R. Physical, electrical and magnetic properties of nanocrystalline Zn-Ni doped Mn-ferrite synthesized by the co-precipitation method. Journal of Alloys and Compounds, 2009, 486, P. 640-644.

[2] Singhal S., Chandra K. Cation distribution and magnetic properties in chromium-substituted nickel ferrites prepared using aerosol route. Journal of Solid State Chemistry, 2007, 180, P. 296-300.

[3] Seyyed Ebrahimi S.A., Azadmanjiri J. Evaluation of $\mathrm{NiFe}_{2} \mathrm{O}_{4}$ ferrite nanocrystalline powder synthesized by a sol-gel auto-combustion method. Journal of Non-Crystalline Solids, 2007, 353, P. 802-804.

[4] Al Angari Y.M. Magnetic properties of La-substituted $\mathrm{NiFe}_{2} \mathrm{O}_{4}$ via egg-white precursor route. Journal of Magnetism and Magnetic Materials, 2011, 323, P. 1835-1839.

[5] Nguyen A.T., Phan Ph.H.Nh., Mittova I.Ya., Knurova M.V., Mittova V.O. The characterization of nanosized $\mathrm{ZnFe}_{2} \mathrm{O}_{4}$ material prepared by coprecipitation. Nanosystems: Physics, Chemistry, Mathematics, 2016, 7(3), P. 459-463.

[6] Karthick R., Ramachandran K., Srinivasan R. Study of Faraday effect on $\mathrm{Co}_{1-x} \mathrm{Zn}_{x} \mathrm{Fe}_{2} \mathrm{O}_{4}$ nanoferrofluids. Nanosystems: Physics, Chemistry, Mathematics, 2016, 7(4), P. 624-628.

[7] Lomanova N.A., Gusarov V.V. Influence of synthesis temperature on $\mathrm{BiFeO}_{3}$ nanoparticles formation. Nanosystems: Physics, Chemistry, Mathematics, 2013, 4(5), P. 696-705.

[8] Kuznetsova V.A., Almjasheva O.V., Gusarov V.V. Influence of microwave and ultrasonic treatment on the formation of CoFe $\mathrm{O}_{4}$ under hydrothermal conditions. Glass Physics and Chemistry, 2009, 35(2), P. 205-209.

[9] Almjasheva O.V., Gusarov V.V. Prenucleation formations in control over synthesis of $\mathrm{CoFe}_{2} \mathrm{O}_{4}$ nanocrystalline powders. Russian Journal of Applied Chemistry, 2016, 89(6), P. 851-856.

[10] Gabal M.A., Ata-Allah S.S. Effect of diamagnetic substitution on the structural. Electrical and magnetic properties of CoFe ${ }_{2} \mathrm{O}_{4} . \mathrm{Materials}$ Chemistry and Physics, 2004, 85, P. 104-112.

[11] He H.-Y. Structural and magnetic property of $\mathrm{Co}_{1-x} \mathrm{Ni}_{x} \mathrm{Fe}_{2} \mathrm{O}_{4}$ nanoparticles synthesized by hydrothermal method. International J. of Applied Ceramic Technology, 2014, 11, P. 626-636.

[12] Maaz K., Khalid W., Mumtaz A., Hasanain S.K., Liu J., Duan J.L. Magnetic characterization of $\mathrm{Co}_{1-x} \mathrm{Ni}_{x} \mathrm{Fe}_{2} \mathrm{O}_{4}$ nanoparticles prepared by co-precipitation route. Physical E: Low-dimensional Systems and Nanostructures, 2009, 41, P. 593-599.

[13] Girgis E., Wahsh M. M.S., Othman A.G.M., Bandhu L., Rao. K.V. Synthesis. Magnetic and optical properties of core/shell $\mathrm{Co}_{1-x} \mathrm{Zn}_{x} \mathrm{Fe}_{2} \mathrm{O}_{4} / \mathrm{SiO}_{2}$ nanoparticles. Nanoscale Res Lett, 2011, 6, P. 460-464.

[14] Maaz K., Karim S., Mashiatullah A., Liu J., Hou M.D., Sun Y.M., Duan J.L., Yao H.J., Mo D., Chen Y.F. Structural analysis of nickel doped cobalt ferrite nanoparticles prepared by coprecipitation route. Physica B: Condensed Matter, 2009, 404, P. 3947-3951.

[15] Nguyen Anh Tien, Mittova I.Ya., Almjasheva O.V., Kirillova S.A., Gusarov V.V. Influence of the preparation condition on the size and morphology of nanocrystalline lanthanum orthoferrite. Glass Physics and Chemistry, 2008, 34(6), P. 756-761.

[16] Nguyen Anh Tien, Mittova I.Ya., Almjasheva O.V. Influence of the synthesis conditions on the particle size and morphology of yttrium orthoferrite obtained from aqueous solutions. Russian Journal of Applied Chemistry, 2009, 82(11), P. 1915-1918.

[17] Kubickova S., Vejpravova J., Holec P., Niznansky D. Correlation of crystal structure and magnetic properties of Co $\mathrm{Co}_{1-x} \mathrm{Ni}_{x} \mathrm{Fe}_{2} \mathrm{O}_{4}$ nanocomposites. Journal of Magnetism and Magnetic materials, 2013, 334, P. 102-106.

[18] Zalite I., Heidemane G., Kodols M., Grabis J., Maiorov M. The synthesis, characterization and sintering of nickel and cobalt ferrite nanopowders. Materials Science, 2012, 18(1), P. 120-124. 